\title{
RAZVOJ NARODNIH KNJIŽNICA \\ U HRVATSKOJ PREMA ZELENIM KNJIŽNICAMA
}

\author{
THE DEVELOPMENT OF PUBLIC LIBRARIES \\ IN CROATIA TOWARDS GREEN LIBRARIES
}

\author{
Radovan Vrana \\ Odsjek za informacijske i komunikacijske znanosti \\ Filozofski fakultet Sveučilišta u Zagrebu \\ rvrana@ffzg.hr \\ Ana Zečević \\ Odsjek za informacijske i komunikacijske znanosti \\ Filozofski fakultet Sveučilišta u Zagrebu \\ azecevic013@gmail.com
}

UDK / UDC 027.022:502/504(497.5)

Izvorni znanstveni rad / Original scientific paper

Primljeno / Received: 2. 3. 2020.

Prihvaćeno / Accepted: 20. 5. 2020.

\section{Sažetak ${ }^{1}$}

Cilj. Rad je posvećen pokretu zelenih knjižnica u Republici Hrvatskoj, s naglaskom na narodne knjižnice. Uz uvodni dio o konceptu zelenih knjižnica, rad u svojem središnjem dijelu nudi prikaz rezultata istraživanja u narodnim knjižnicama u RH o temi zelenih knjižnica. Cilj istraživanja bio je utvrditi trenutno stanje i istražiti razvijaju li se narodne knjižnice u Republici Hrvatskoj prema zelenim knjižnicama ispitivanjem sljedećih triju elemenata zelene knjižnice: zgrada knjižnice, poslovanje zelene knjižnice te knjižnične usluge.

1 Članak je nastao na temelju diplomskog rada Ane Zečević „Razvoj narodnih knjižnica u Hrvatskoj prema zelenim knjižnicama“, napisanog pod mentorskim vodstvom Radovana Vrane. Rad je obranjen 2019. godine na Odsjeku za informacijske i komunikacijske znanosti Filozofskog fakulteta Sveučilišta u Zagrebu..

Vjesnik bibliotekara Hrvatske 63, 1-2(2020), 365-388 ISSN 0507-1925 
Pristup/metodologija/dizajn. Uvodni teorijski dio rada napisan je prema dostupnoj literaturi, dok je središnji dio rada posvećen istraživanju u kojem je korištena metoda ankete provedena uz pomoć online anketnog upitnika. Uzorak istraživanja odnosi se na sve narodne knjižnice u RH kako bi se stvorila cjelovita slika o temi zelenih knjižnica u narodnim knjižnicama u RH.

Rezultati. Istraživanje u kojem su sudjelovale 82 narodne knjižnice u RH pokazalo je da većina knjižnica u zgradama ne provodi financijski dostupne mjere štednje energije, ali da su neka od načela zelenog poslovanja ipak zastupljena u njihovom poslovanju (odvajanje papira za reciklažu te štednja papira i tinte u većini knjižnica). Utvrđeno je da su ispitane knjižnice zainteresirane za razvijanje zelenih knjižničnih usluga te da većina knjižnica u svoj program uvrštava i događanja ekološke tematike. Međutim iz provedene ankete proizlazi i to da je potrebno educirati same knjižničare o konceptu zelene knjižnice, motivirati ih te kod njih razvijati ekološku svijest. Osim nedovoljne educiranosti ili zainteresiranosti zaposlenika za koncept zelene knjižnice, pokazalo se da prepreka razvoju narodnih knjižnica u Hrvatskoj u zelenom smjeru mogu biti nedovoljan broj knjižničnog osoblja, neodgovarajući prostor te nedostatak financijskih sredstava.

Originalnost/vrijednost. Rad predstavlja sveobuhvatno istraživanje o zelenim knjižnicama na nacionalnoj razini te su njegovi rezultati primjenjivi u razvoju narodnih knjižnica u RH.

Ključne riječi: ekologija, narodne knjižnice, održivi razvoj, zelene knjižnice

\section{Abstract ${ }^{2}$}

Purpose. This paper deals with the Green Library Movement in the Republic of Croatia, with an emphasis on public libraries in Croatia. After the introductory part about the green libraries, the central part of the paper presents the results of the research about green libraries in the public libraries in Croatia. The aim of the research was to determine the current situation and to examine whether the public libraries in Croatia are developing towards green libraries by examining the following three elements of a green library: the library building, the green operation, and library services.

Approach/methodology/design. The introductory part of the article is based on the available literature about green libraries, while the central part presents the research that used an online questionnaire as a research method. The research aimed to include all public libraries in the Republic of Croatia.

Findings. The research was carried out in 82 public libraries in Croatia and it has shown that the majority of libraries did not apply financially available measures for

\footnotetext{
2 The article is based on the graduation thesis written by Ana Zečević „The Development of Public Libraries in Croatia towards Green Libraries" supervised by professor Radovan Vrana. The thesis was defended in 2019 at the Department of Information and Communication Sciences, Faculty of Humanities and Social Sciences, University of Zagreb.
} 
energy saving, although some principles of green operation were present in libraries (waste sorting, paper saving, printer cartridge saving). The results indicate a considerable interest of public libraries in Croatia in the development of green library services and that the majority of libraries include ecological topics in their activity plans. However, the research results also indicate the need for additional education of librarians about green library concept in order to motivate librarians to develop ecological awareness. In addition to the insufficient education of librarians about the concept of green libraries, the insufficient number of library staff is also a problem in the public library development in Croatia, as well as inadequate library space and facilities, and lack of financial means.

Originality/value. The paper presents a comprehensive research about green libraries on the national level and its results are applicable in the future development of public libraries in the Republic of Croatia.

Keywords: ecology, green libraries, public libraries, sustainable development

\section{Uvod}

Knjižnice 21. stoljeća više nisu samo mjesta koja posjeduju te korisnicima posuđuju knjižnu i neknjižnu građu, već su mjesta koja, ako žele zadržati korisnike, moraju osluškivati njihove potrebe te pratiti promjene u društvu. Jedna je od bitnih promjena u društvu sve veće zagađenje okoliša koje vodi prema njegovu uništenju. Knjižnice, kao mjesta koja podupiranjem obrazovanja doprinose napretku društva, problem okoliša ne bi trebale zanemarivati, već bi trebale raditi na njegovu rješavanju kako bi očuvale društvo kojemu služe.

Nekoliko je načina na koji knjižnice mogu doprinijeti očuvanju okoliša te smanjiti svoj negativan utjecaj na njega. Jedan od načina izgradnja je knjižnične zgrade u skladu s načelima zelene gradnje. Upravo je knjižnična zgrada u središtu definicije pojma ,zelene (engl. green library) ili održive knjižnice“ (engl. sustainable library) navedene u online rječniku knjižničarstva i informacijskih znanosti Online Dictionary for Library and Information Science (ODLIS). Prema tom rječniku termin „održiva knjižnica“ označava knjižnicu dizajniranu tako da negativan utjecaj na okoliš svede na najmanju moguću mjeru, a poveća što je više moguće kvalitetu unutarnjeg okoliša pažljivim odabirom lokacije knjižnice, upotrebom prirodnih građevinskih materijala i biorazgradivih proizvoda, štednjom resursa (vode, energije, papira) te odgovornim odlaganjem otpada (recikliranje, itd.). Termini održiva knjižnica i zelena knjižnica prema tom su rječniku sinonimi. ${ }^{3}$

Međutim sami smještaj knjižnice u održivu zgradu ne čini knjižnicu zelenom knjižnicom. Zelena knjižnica u pravom smislu bila bi spoj triju elemenata: održive

3 Sustainable library. // Online Dictionary of Library and Information Science. [citirano: 201907-16]. Dostupno na: https://www.abc-clio.com/ODLIS/odlis_s.aspx\#sustainablelib. 
zgrade izgrađene po načelima zelene gradnje, zelenog poslovanja te aktivnog pružanja zelenih knjižničnih usluga. Mnoge knjižnice zbog nedostatka financijskih sredstava ne mogu imati održive zgrade, stoga zelene knjižnice u smislu zelene knjižnične zgrade u radu neće biti pobliže razmatrane. Ono što knjižnice mogu učiniti, a to ovisi ponajprije o motivaciji rukovodstva i zaposlenika, uvođenje je zelenog poslovanja te ponuda zelenih knjižničnih usluga za korisnike.

\section{Poslovanje i aktivnosti zelene knjižnice}

Kao što je već navedeno, pojam „zelene knjižnice“ može se odnositi i na one knjižnice koje nisu smještene u održivoj zgradi, ali su svoje poslovanje učinile ekološki prihvatljivijim. Činjenica je da knjižnice iskorištavaju prirodne resurse i stvaraju otpad, pa stoga ni negativan utjecaj poslovanja knjižnica na okoliš nije zanemariv. Jedno od rješenja prelazak je na zeleno poslovanje. Zeleno poslovanje dio je društveno odgovornog poslovanja koje uključuje štednju energije i resursa, smanjenje otpada te njegovo recikliranje, nabavu i upotrebu ekoloških proizvoda te suradnju s lokalnom zajednicom i vlastima u području zaštite okoliša. ${ }^{4}$ Male promjene na razini pojedinca mogu učiniti velike promjene na razini organizacije te je $\mathrm{u}$ tom kontekstu razvijen koncept zelenog ureda. Zeleni ured odnosi se na niz aktivnosti koje se svakodnevno primjenjuju u uredskom poslovanju, a kojima se smanjuje negativan utjecaj na okoliš te povećava učinkovitost korištenja resursa (učinkovito korištenje energije i materijala, smanjenje otpada te recikliranje). ${ }^{5}$

Osim održivom zgradom i zelenim poslovanjem, knjižnice mogu biti zelene po svojim uslugama kojima promiču održivi razvoj i zaštitu okoliša. Zelene knjižnične usluge odnose se na ponudu informacija okolišne tematike, na ekološku edukaciju korisnika i zaposlenika knjižnice kroz različite tematske aktivnosti i programe, ali i na posudbu neknjižne građe kao što je, primjerice, alat. ${ }^{6}$ Različitim aktivnostima i projektima okolišne tematike razvijaju zelenu pismenost ${ }^{7}$ kod ko- $^{-}$ risnika, a njihova provedba ovisi ponajprije o zainteresiranosti knjižničara. Bačić ističe da knjižničari kao odgovorni profesionalci, sukladno svom poslanju i etičkim normama, imaju obvezu poduzimati potrebne aktivnosti vezane za unapređivanje života zajednice kojoj služe. ${ }^{8}$

\footnotetext{
4 Poticanje energetske efikasnosti u Hrvatskoj. Društveno odgovorno poslovanje. [citirano 201907-16]. Dostupno na: http://www.enu.fzoeu.hr/hio/zeleni-ured/drustveno-odgovorno-poslovanje.

5 Vodič kroz Zeleni ured: priručnik. [citirano 2019-07-16]. Dostupno na: http://www.enu.fzoeu. $\mathrm{hr} /$ assets/files/shared/list/zuPrirucnik.pdf.

6 Usp. Sahavirta, H. Set the wheels in motion - clarifying "green library" as a goal for action. // Libraries: dialogue for change / IFLA World Library and Information Congress (WLIC) 2019, Atena. [citirano: 2019-08-27]. Dostupno na: http://library.ifla.org/2568/1/166-sahavirta-en.pdf.

7 Čadovska, I.; A.-M. Tkalčić. Zelena pismenost kao dio strategije razvoja informacijske službe. // Vjesnik bibliotekara Hrvatske 60, 1(2017), str. 69.

8 Bačić, E. Zagovaranje za knjižnice i partnerstvo za održivi razvoj. // Vjesnik bibliotekara Hrvatske 61, 2(2018), str. 370. Dostupno i na: https://www.hkdrustvo.hr/vjesnik-bibliotekara-hrvatske/index.php/vbh/article/view/707/608 [citirano: 2019-07-16].
} 
IFLA (International Federation of Library Associations and Institutions) je 2009. godine shvatila kako bi knjižnice uvelike mogle doprinijeti održivosti, ali da mnogi knjižničari ne posvećuju pozornost ekološkim problemima. Kako bi se to promijenilo, unutar IFLA-e osnovana je Radna skupina za okoliš, održivost i knjižnice (Environment, Sustainability and Libraries Special Interest Group, dalje u tekstu ENSULIB). Skupina se bavi sljedećim pitanjima: učincima klimatskih promjena na knjižnice, uvođenjem ekološki prihvatljivih praksi u knjižnice, preporukama za zaštitu okoliša unutar knjižničarske struke, povećanjem i promocijom informacijskih izvora i usluga koje se bave pitanjima održivoga razvoja i zaštitom okoliša te razvijanjem ekološke osviještenosti samih knjižničara. ${ }^{9}$

Kako bi nagradila knjižnice koje se posvećuju zaštiti okoliša te stvorila svijest o društvenoj odgovornosti knjižnice i njezinoj ulozi u obrazovanju za okoliš, ENSULIB od 2016. godine dodjeljuje Nagradu za najbolju zelenu knjižnicu (Green Library Award). U 2016. godini na natječaj se prijavilo 30 knjižnica, 2017. godine 35 knjižnica, 2018. godine 32 , a u 2019. godini 34 knjižnice. ${ }^{10}$

\section{Pokret zelenih knjižnica u Hrvatskoj}

Ideja zelene knjižnice u Hrvatskoj pojavila se 2011. godine kada je Društvo bibliotekara Istre, pod vodstvom tadašnjeg predsjednika Društva Ivana Kraljevića, pokrenulo projekt Zelena knjižnica u sklopu kojeg su organizirane brojne aktivnosti: projekcije filmova ekološke tematike, predavanja, tribine te promocije knjiga. Do kraja 2018. godine održane su 162 aktivnosti, a posjetilo ih je 8000 korisnika. Većina aktivnosti provedena je u Sveučilišnoj knjižnici u Puli te na Fakultetu ekonomije i turizma „Dr. Mijo Mirković“. U projekt su od početka bile uključene narodne knjižnice u Puli, Pazinu, Umagu, Buzetu, Labinu, Rovinju, Poreču i Novigradu. ${ }^{11}$

Širenju ideje zelene knjižnice doprinijelo je predstavljanje projekta na 38. skupštini Hrvatskog knjižničarskog društva održanoj 2012. godine u Osijeku. To je ujedno bilo i prvo izlaganje o zelenim knjižnicama u Hrvatskoj. Nakon toga uključile su se narodne knjižnice iz drugih dijelova Hrvatske - Knjižnica i čitaonica „Fran Galović“" Koprivnica, Knjižnica „Juraj Šižgorić“ Šibenik te Gradska knjižnica Vukovar. Uključivanjem većeg broja knjižnica javila se potreba za osnivanjem tijela koje bi koordiniralo suradnju zelenih knjižnica te radilo na njihovoj promociji. ${ }^{12}$

9 IFLA. About the Environment, Sustainability and Libraries Special Interest Group. [citirano: 2019-08-09]. Dostupno na: https://www.ifla.org/about-environmental-sustainability-and-libraries.

10 IFLA. IFLA Green Library Award. [citirano: 2019-08-09]. Dostupno na: https://www.ifla.org/ node/10159.

11 Kraljević, I. Djelovanje radne grupe za zelene knjižnice: 2014.-2018. // Vjesnik bibliotekara Hrvatske 62, 1(2019), str. 329. Dostupno i na: http://www.hkdrustvo.hr/vjesnik-bibliotekara-hrvatske/index.php/vbh/article/view/720/640 [citirano: 2019-07-26].

12 Isto. 
Sljedeća, 39. skupština Hrvatskog knjižničarskog društva, održana u Splitu 2014. godine s temom „Knjižnice - od misije do strategije“, imala je za cilj preispitati postojeće stanje te pokušati odrediti pravce razvoja hrvatskih knjižnica i hrvatskoga knjižničarstva gledano iz perspektive tehnoloških i društvenih promjena koje utječu na rad knjižnica i potiču trendove u knjižničarstvu. ${ }^{13}$ Tema je posvećena i zelenim knjižnicama te je osnovana Radna grupa za zelene knjižnice pri Sekciji za upravljanje i tehnologiju Hrvatskog knjižničarskog društva. Članovi osnivači bili su Edita Bačić (Pravna knjižnica Sveučilišta u Splitu), Melinda Grubišić Reiter (Knjižnica „Juraj Šižgorić“ Šibenik), Dijana Sabolović-Krajina i Petar Lukačić (Knjižnica i čitaonica „Fran Galović“" Koprivnica) te Ivan Kraljević (Sveučilišna knjižnica u Puli) u svojstvu predsjednika. ${ }^{14}$ Grupa je osnovana kako bi uspostavila mrežu knjižnica prema obrascu istarskog projekta u svrhu edukacije javnosti i podizanja svijesti o održivom društvu i nužnosti zaštite okoliša kroz knjižnice i knjižničarska društva, a bavi se i pitanjima energetske učinkovitosti u knjižnicama. ${ }^{15}$

Od veljače do travnja 2015. godine Grupa je provodila online anketu među hrvatskim knjižnicama kako bi pronašla knjižnice zainteresirane za sudjelovanje u projektu Zelena knjižnica. U anketi su sudjelovale 174 knjižnice, tj. $10 \%$ svih knjižnica u Hrvatskoj, od čega su 29 \% činile narodne knjižnice. Rezultati ankete pokazali su da su knjižničari zainteresirani za sudjelovanje u projektu, te je Radna grupa odlučila nastaviti nuditi informacije i poduku za knjižničare u obliku predavanja, radionica te promocije održivog razvoja u društvu. ${ }^{16}$ Od svoga osnutka do danas organizirala je brojna predavanja o zelenim knjižnicama, ciklus tribina pod nazivom OdrŽive tribine, eko izložbe i druga događanja, a svake godine u suradnji s udrugom „Zelena akcija“ provodi nacionalnu akciju Pokrenimo zelene knjižnice u sklopu koje knjižnice mogu besplatno preuzeti i prikazivati filmove s E?! - Okolišnog film festivala. ${ }^{17}$

U travnju 2016. godine Knjižnica Ekonomskog fakulteta u Osijeku organizirala je okrugli stol pod nazivom „Kreiranje knjižnica zelene boje“. Svrha okruglog stola bila je da knjižnice sudionice predstave svoje eko projekte, da se dogovore aktivnosti usmjerene na informiranje i educiranje javnosti, širenje svijesti o održivom razvoju, nužnosti zaštite okoliša te korisnosti pravilnog gospodarenja otpadom. ${ }^{18}$

13 Hrvatsko knjižničarsko društvo. 39. skupština Hrvatskoga knjižničarskog društva. [citirano: 2019-07-26]. Dostupno na: http://hkdrustvo.hr/hr/skupovi/skup/241/.

14 Kraljević, I. Nav. dj., str. 329-330.

15 Hrvatsko knjižničarsko društvo. Radna grupa za zelene knjižnice - Uvod. [citirano: 2019-0726]. Dostupno na: https://www.hkdrustvo.hr/hr/strucna_tijela/50.

16 Izvještaj Radne grupe za zelene knjižnice za 2015. godinu. [citirano: 2019-07-26]. Dostupno na: http://hkdrustvo.hr/hr/strucna_tijela/50/publikacije.

17 Hrvatsko knjižničarsko društvo. Radna grupa za zelene knjižnice - Plan i program. [citirano: 2019-07-29]. Dostupno na: https://www.hkdrustvo.hr/hr/strucna_tijela/50/plan_i_program/.

18 Ekonomski fakultet u Osijeku. Okrugli stol. [citirano: 2019-07-26]. Dostupno na: http://www. efos.unios.hr/knjiznica/okrugli-stol/. 
Na 41. skupštini Hrvatskog knjižničarskog društva održanoj 2016. godine u Primoštenu jedna od podtema bila je „Knjižnice kao prostor i zelena knjižnica“. ${ }^{19}$ Održano je sedam izlaganja u tematskom bloku „Zelena knjižnica - prilagodba knjižnica promjenama u suvremenom društvu" te su izložena dva postera s istom temom..$^{20}$ Svrha predavanja bila je podizanje svijesti o nužnosti uključivanja u takve projekte, motiviranje knjižničara i dijeljenje iskustva i znanja o provedbi projekta. $^{21}$

U svibnju 2016. godine Nacionalna i sveučilišna knjižnica u Zagrebu pokrenula je projekt Zelena knjižnica za zelenu Hrvatsku kojim se nastoji educirati korisnike te popularizirati teme iz područja zaštite okoliša. ${ }^{22}$ Iste godine u Knjižnici je održan još jedan okrugli stol s temom „Zelene knjižnice“ kako bi se javnost osvijestilo o uslugama, aktivnostima, događanjima, izdanjima i projektima koje knjižnice u Hrvatskoj provode kao društveno odgovorne ustanove i predvodnice u širem usvajanju i provođenju načela ekološki održivoga razvoja. ${ }^{23}$ Moderator okruglog stola bio je Mladen Iličković, autor i urednik emisije Eko zona, koji je tada istaknuo važnost umrežavanja ustanova različitih profila koje imaju isti cilj, a to je educirati i informirati te na taj način osvijestiti o potrebi ekološkog djelovanja. $^{24}$

U širenju koncepta zelene knjižnice veliku ulogu ima mrežna stranica projekta Zelena knjižnica koja povezuje sudionike i korisnike projekta. Na njoj se objavljuju najave aktivnosti knjižnica (predavanja, radionice, promocije knjiga, projekcije filmova) te osvrti na aktivnosti. Osim vijesti o aktivnostima, mogu se pregledavati i fotografije te kratki filmovi vezani za aktivnosti, ali i poučni filmovi iz područja ekologije te ostali sadržaji vezani za održivi razvoj i zaštitu okoliša. $^{25}$

19 Hrvatsko knjižničarsko društvo. 41. skupština Hrvatskoga knjižničarskog društva. [citirano: 2019-07-26]. Dostupno na: http://hkdrustvo.hr/hr/skupovi/skup/302/.

20 Izvještaj Radne grupe za zelene knjižnice za 2016. godinu. [citirano: 2019-07-26]. Dostupno na: http://hkdrustvo.hr/hr/strucna_tijela/50/publikacije.

${ }^{21}$ Izvještaj Radne grupe za zelene knjižnice za 2015. godinu. [citirano: 2019-07-26]. Dostupno na: http://hkdrustvo.hr/hr/strucna_tijela/50/publikacije.

22 Projekt Zelena knjižnica za zelenu Hrvatsku. // HKD Novosti 73(2017). [citirano: 2019-0729]. Dostupno na: http://www.hkdrustvo.hr/hkdnovosti/clanak/1331.

${ }^{23}$ Nacionalna i sveučilišna knjižnica u Zagrebu. „Zelene knjižnice“: održan okrugli stol o knjižnicama kao predvodnicama ekološki održivoga razvoja. [citirano: 2019-07-29]. Dostupno na: http://www.nsk.hr/zelene-knjiznice-odrzan-okrugli-stol-o-knjiznicama-kao-predvodnicama-ekoloski-odrzivoga-razvoja/.

24 Projekt Zelena knjižnica za zelenu Hrvatsku. // HKD Novosti 73(2017). [citirano: 2019-0729]. Dostupno na: http://www.hkdrustvo.hr/hkdnovosti/clanak/1331.

${ }_{25}$ Kraljević, I. Zelena knjižnica: projekt Društva bibliotekara Istre. // Vjesnik bibliotekara Hrvatske 56, 3(2013), str. 202. Dostupno i na: https://www.hkdrustvo.hr/vjesnik-bibliotekara-hrvatske/index.php/vbh/article/view/170 [citirano: 2019-07-26]. 


\section{Istraživanje razvoja narodnih knjižnica u Hrvatskoj prema zele- nim knjižnicama}

\subsection{Uvod u istraživanje}

U radu se istražuje razvoj narodnih knjižnica u Hrvatskoj prema zelenim knjižnicama. Budući da u Hrvatskoj ne postoje narodne knjižnice čije su zgrade u potpunosti izgrađene u skladu s načelima zelene gradnje, istraživanje je bilo usmjereno na čimbenike na koje knjižnice mogu utjecati - na potrošnju energije i resursa, izgradnju zelenih knjižničnih zbirki, provođenje zelenih knjižničnih aktivnosti i programa te na promociju istih.

\subsection{Svrha i cilj istraživanja}

Svrha istraživanja bila je utvrditi stavove narodnih knjižnica u Republici Hrvatskoj o konceptu zelene knjižnice. Narodne knjižnice kao mjesta okupljanja i pružanja informacija svim društvenim skupinama, uvođenjem manjih i većih promjena u svoje poslovanje te organiziranjem različitih zelenih aktivnosti i programa za knjižničare i korisnike, mogu pridonijeti očuvanju okoliša.

Cilj istraživanja bio je utvrditi trenutno stanje i istražiti razvijaju li se narodne knjižnice u Republici Hrvatskoj prema zelenim knjižnicama ispitivanjem sljedećih triju elemenata zelene knjižnice: zgrada knjižnice, poslovanje zelene knjižnice i knjižnične usluge. Postavljene su tri hipoteze:

1. Zgrade narodnih knjižnica u Hrvatskoj ne razvijaju se u skladu s ekološkom održivosti (H1).

2. U knjižnično poslovanje narodnih knjižnica u Hrvatskoj uvode se načela zelenog poslovanja (H2).

3. Sve više narodnih knjižnica u Hrvatskoj zainteresirano je za razvijanje zelenih knjižničnih usluga $(\mathrm{H} 3)$.

\subsection{Metodologija, instrument i uzorak}

$\mathrm{Za}$ potrebe istraživanja odabrana je metoda ankete, tj. online anketni upitnik. Budući da se istraživanjem nastojalo obuhvatiti sve narodne knjižnice na prostoru Republike Hrvatske, poziv za sudjelovanje poslan je svim narodnim knjižnicama u državi.

Istraživanje je provedeno od 29. srpnja do 17. kolovoza 2019. godine. Poziv na ispunjavanje anketnog upitnika poslan je na ukupno 268 adresa elektroničke pošte, tj. svim narodnim knjižnicama čije su adrese elektroničke pošte bile javno dostupne na njihovim mrežnim stranicama te na Portalu narodnih knjižnica. Online anketni upitnik trebali su ispuniti ravnatelji samostalnih knjižnica, voditelji knjižnica u sastavu, odnosno područnih knjižnica te koordinatori ogranaka na- 
rodnih knjižnica. Razlog tomu je što osobe na navedenim funkcijama imaju više znanja o poslovanju knjižnice kojom upravljaju u odnosu na ostale zaposlenike, kao i najveći utjecaj na donošenje odluka o poslovanju knjižnice te organizaciji i provedbi različitih aktivnosti i programa. U istraživanju su sudjelovale 82 knjižnice, što čini odaziv od $32,6 \%$.

Anketni upitnik bio je podijeljen na uvodni dio te na tri dodatna dijela kojima su se ispitivali pojedini elementi zelene knjižnice. Uvodni dio sastojao se od općih podataka: naziv knjižnice, adresa knjižnice, tip knjižnice (samostalna, u sastavu, područna, ogranak, ostalo) i funkcija ispitanika (ravnatelj, voditelj, koordinator, ostalo). Prvi dio odnosio se na knjižničnu zgradu (3 pitanja), drugi dio na poslovanje zelene knjižnice ( 5 pitanja), a treći dio odnosio se na zelene knjižnične usluge (11 pitanja). Pitanja su bila zatvorenog tipa, a u pojedinim pitanjima bio je omogućen upis dodatnog odgovora. Posljednje pitanje bilo je pitanje otvorenog tipa (Prilog 1: Anketni upitnik).

\subsection{Rezultati istraživanja}

U istraživanju su sudjelovale 82 narodne knjižnice i to: 61 samostalna knjižnica, 11 ogranaka, 7 knjižnica u sastavu te 3 područne knjižnice.

Anketni upitnik ispunila su 54 ravnatelja, 10 voditelja, 10 koordinatora, 3 diplomirana knjižničara, 1 voditeljica razvojne matične službe, 1 knjižničarka, 1 djelatnik, 1 informator te 1 vršitelj dužnosti ravnatelja.

\subsubsection{Zgrada knjižnice}

U prvom pitanju od ispitanika se tražilo da navedu posjeduje li zgrada knjižnice certifikat za zelenu gradnju. Od ukupno 82 knjižnice koje su sudjelovale 79 knjižnica navelo je da zgrada knjižnice nema certifikat za zelenu gradnju $(96,3 \%)$, a 3 knjižnice navele su da zgrada ima navedeni certifikat (3,7 \%).

U drugom se pitanju od knjižnica koje su navele da zgrada nema certifikat za zelenu gradnju tražilo da navedu planira li se izgradnja nove knjižnične zgrade s certifikatom za zelenu gradnju. Od ukupnog broja knjižnica čija zgrada nema takav certifikat 60 knjižnica odgovorilo je da se ne planira izgradnja nove knjižnične zgrade s certifikatom za zelenu gradnju (75,9 \%), 17 knjižnica odgovorilo je da se planira izgradnja nove knjižnične zgrade s certifikatom za zelenu gradnju $(21,5$ $\%)$, a 2 knjižnice nisu odgovorile na pitanje (2,5\%).

U trećem pitanju ispitanici su među ponuđenim odgovorima trebali označiti koje se mjere štednje energije već primjenjuju u zgradi knjižnice, a ostavljena je mogućnost dodatnog odgovora. Rezultati ispitivanja mjera štednje sljedeći su:

- štedne žarulje - 47 knjižnica $(57,3 \%)$

- automatska regulacija grijanja (isključivanje kada u knjižnici nema korisnika niti zaposlenih, tj. kada je knjižnica prazna) - 41 knjižnica (50 \%) 
- prirodna ventilacija - 28 knjižnica (34,1\%)

- automatska regulacija rashladnih uređaja (isključivanje kada u knjižnici nema korisnika niti zaposlenih, tj. kada je knjižnica prazna) - 27 knjižnica $(32,9 \%)$

- senzori za svjetlo - 6 knjižnica $(7,3 \%)$

- korištenje obnovljivih izvora energije - 4 knjižnice $(4,9 \%)$

- ništa od navedenog - 9 knjižnica $(10,8 \%)$.

Kao dodatne odgovore knjižnice su navele:

- u tijeku je obnova krova na zgradi za energetsku učinkovitost - 1 knjižnica $(1,2 \%)$.

\subsubsection{Poslovanje zelene knjižnice}

U prvom pitanju o poslovanju zelene knjižnice od ispitanika se tražilo da navedu ima li knjižnica na svojoj mrežnoj stranici oznaku zelene knjižnice. Od ukupnog broja knjižnica 76 knjižnica navelo je da nema (92,7 \%), a 6 knjižnica navelo je da na svojoj mrežnoj stranici ima oznaku zelene knjižnice (7,3 \%).

Drugim se pitanjem ispitivalo koja od ponuđenih načela zelenog ureda knjižnica već primjenjuje. Ostavljena je i mogućnost dodatnog odgovora. Rezultati su sljedeći:

- odvajanje papira za reciklažu - 80 knjižnica $(97,6 \%)$

- štednja papira i tinte (obostrani ispis, izbjegavanje ispisa i sl.) - 76 knjižnica $(92,7 \%)$

- nekorištenje jednokratne plastike (plastične čaše i dr.) - 27 knjižnica $(32,9 \%)$

- isključivanje računala za vrijeme stanke - 23 knjižnice (28 \%).

Kao dodatne odgovore knjižnice su navele:

- smanjeno korištenje plastike i ,zeleni“ programi - 1 knjižnica $(1,2 \%)$

- odvajanje elektroničkog otpada - 1 knjižnica (1,2 \%)

- skupljanje istrošenih baterija, organiziranje informativnih eko izložbi za korisnike, uređivanje interijera sobnim biljkama - 1 knjižnica (1,2 \%)

- odvajanje svih vrsta otpada - 1 knjižnica $(1,2 \%)$

- odvajanje plastičnog otpada - 1 knjižnica $(1,2 \%)$.

U sljedećem pitanju ispitanici su trebali odgovoriti surađuje li knjižnica s ustanovama, udrugama i pojedincima iz područja ekologije. Od ukupnog broja knjižnica 58 ih je odgovorilo da surađuje (70,7 \%), a 24 knjižnice odgovorile su negativno $(29,3 \%)$. 
Nadalje, od knjižnica koje su odgovorile da surađuju s ustanovama, udrugama i pojedincima iz područja ekologije tražilo se da među ponuđenim odgovorima označe s kim knjižnica surađuje u provođenju zelenih knjižničnih programa. Ponuđena je mogućnost dodatnog odgovora. Rezultati su pokazali da knjižnice surađuju:

- s osnovnim i srednjim školama - 45 knjižnica $(80,4 \%)$

- s udrugama - 39 knjižnica $(69,6 \%)$

- s pojedinim stručnjacima - 26 knjižnica $(46,4 \%)$

- s drugim knjižnicama - 21 knjižnica $(37,5 \%)$

- s gradom - 20 knjižnica $(35,7 \%)$

- s općinom - 16 knjižnica $(28,6 \%)$

- s fakultetima -7 knjižnica $(12,5 \%)$.

Kao dodatne odgovore knjižnice su navele:

- komunalno poduzeće - 2 knjižnice $(3,6 \%)$.

U posljednjem pitanju cjeline od ispitanika se tražilo da ocjenama od (1) (nisam upoznat/a) do (5) (odlično) ocijene koliko su dobro upoznati s konceptom zelene knjižnice:

- (1) - 6 ispitanika $(7,3 \%)$

- (2) -7 ispitanika $(8,5 \%)$

- (3) - 36 ispitanika $(43,9 \%)$

- (4) - 27 ispitanika $(32,9 \%)$

- (5) -6 ispitanika $(7,3 \%)$.

\subsubsection{Knjižnične usluge}

Prvim pitanjem u cjelini o zelenim knjižničnim uslugama ispitivalo se posjedovanje tiskane i/ili elektroničke građe s područja zaštite i očuvanja okoliša. Od ukupnog broja knjižnica njih 77 odgovorilo je da posjeduje građu s područja zaštite i očuvanja okoliša (93,9\%), a 5 knjižnica odgovorilo je da ne posjeduje navedenu građu $(6,1 \%)$.

Drugo pitanje odnosilo se na uključenost knjižnice u neki od postojećih projekata i programa za zelenu knjižnicu (Pokrenimo zelene knjižnice, Zelene knjižnice za zeleni Zagreb, ZeeK i dr.). Tako je 66 knjižnica odgovorilo da knjižnica ne sudjeluje u zelenim projektima i programima (80,5\%), dok je njih 16 odgovorilo da sudjeluje $(19,5 \%)$.

Od knjižnica koje su pozitivno odgovorile na prethodno pitanje u sljedećem se pitanju tražilo da navedu nazive projekata i programa za zelenu knjižnicu u 
kojima sudjeluju. Od 16 knjižnica odgovorilo je njih 10. Dobiveni su sljedeći odgovori:

- Zelena knjižnica za zeleni Zagreb - 4 knjižnice

- Zelena knjižnica - 1 knjižnica

- Pokrenimo zelene knjižnice - 2 knjižnice

- edukativne radionice o održivom gospodarenju otpadom Zato što volim Zadar - 1 knjižnica

- Zavičajne čajanke, Projekt zelene knjižnice, U ugodnom društvu pričamo zeleno - 1 knjižnica

- povremeno se uključujemo u projekte - 1 knjižnica.

U nastavku se od knjižnica koje su odgovorile da ne sudjeluju u projektima za zelenu knjižnicu nastojalo utvrditi planira li se knjižnica uključiti u takve projekte. Njih 40 odgovorilo je da se planira uključiti $(60,6 \%)$, ne planira se uključiti 13 knjižnica (19,7 \%), a 13 knjižnica nije odgovorilo (19,7 \%).

U sljedećem se pitanju od ispitanika tražilo da navedu organizira li knjižnica događanja ekološke tematike. Većina knjižnica, njih 67 (81,7 \%), navela je da knjižnica organizira takva događanja, dok je 15 ispitanika navelo da ih ne organizira $(18,3 \%)$.

Zatim se od ispitanika koji su pozitivno odgovorili na prethodno pitanje tražilo da označe vrstu događanja ekološke tematike koja su već održana ili se provode. Ponuđena je mogućnost dodatnog odgovora. Rezultati su sljedeći:

- radionice - 56 knjižnica $(83,6 \%)$

- predavanja - 50 knjižnica $(74,6 \%)$

- izložbe - 41 knjižnica $(61,2 \%)$

- tribine za javnost - 16 knjižnica $(23,9 \%)$

- projekcije filmova - 14 knjižnica $(20,9 \%)$

- predstave - 11 knjižnica $(16,4 \%)$

- seminari - 4 knjižnice (6\%).

Kao dodatne odgovore knjižnice su navele:

- sudjelovanje u akcijama - 1 knjižnica $(1,5 \%)$

- izdavanje kompleta od 6 slikovnica - održivo gospodarenje otpadom; teme: razvrstavanje otpada, recikliranje, kompostiranje, obnovljivi izvori energije, čiste vode, čisti zrak - 1 knjižnica $(1,5 \%)$

- pričaonica i radionice za djecu - 1 knjižnica $(1,5 \%)$

- razmjena sjemenja starih sorti - 1 knjižnica (1,5\%)

- mali festival za djecu Happyfest s naglaskom na eko tematiku i zdravu prehranu - 1 knjižnica $(1,5 \%)$ 
- akcije na otvorenom: Najveća bojanka u gradu, Vježbanje s knjigom, Biciklistički poligon - Pedala... - 1 knjižnica (1,5\%)

- u pripremi su ekološke radionice za 2020., a namjera je i organizirati predavanje - 1 knjižnica $(1,5 \%)$

- predstavljanja knjiga - 1 knjižnica (1,5\%)

- Knjižnica je izradila brošure s temom permakulture! - 1 knjižnica (1,5 \%).

Sljedeće pitanje odnosilo se na promociju zelenih aktivnosti. Na pitanje promovira li knjižnica svoje zelene aktivnosti 52 knjižnice odgovorile su da promoviraju (63,4\%), a 30 ih je odgovorilo da ne promovira (36,6\%). Budući da je 15 knjižnica odgovorilo kako ne organizira događanja ekološke tematike, može se pretpostaviti da se među 30 knjižnica koje ne promoviraju svoje zelene aktivnosti nalaze upravo te knjižnice, dok 15 knjižnica koje organiziraju događanja ekološke tematike ista ta događanja ne promovira.

Dalje se od ispitanika koji su pozitivno odgovorili na prethodno pitanje tražilo da među ponuđenim odgovorima označe gdje knjižnica promovira svoje zelene aktivnosti. Na pitanje je odgovorilo 50 knjižnica od ukupno 52 koje su u prethodnom pitanju navele da promoviraju svoje zelene aktivnosti. I ovdje je ostavljena mogućnost dodatnog odgovora. Rezultati su pokazali da knjižnice svoje aktivnosti promoviraju:

- na društvenim mrežama - 37 knjižnica (74 \%)

- na vlastitoj mrežnoj stranici - 36 knjižnica (72 \%)

- na plakatima - 34 knjižnice (68 \%)

- putem newslettera - 3 knjižnice (6\%).

Kao dodatne odgovore knjižnice su navele:

- u lokalnim medijima i na mrežnim portalima - 1 knjižnica (2\%)

- mailing lista prema lokalnim medijima - 1 knjižnica (2\%)

- mediji (radio, novine) - 2 knjižnice (4 \%).

Sljedećim pitanjem nastojalo se ispitati mišljenje zaposlenika o ulozi narodne knjižnice u izobrazbi o zaštiti okoliša. Na ljestvici od (1) (potpuno nevažno) do (5) (vrlo važno) odgovarali su na pitanje: Koliko je važno da se narodne knjižnice svojim uslugama (zbirkama i organiziranjem događanja) uključe u izobrazbu o zaštiti okoliša?

- (1) - 0 ispitanika (0\%)

- (2) - 0 ispitanika $(0 \%)$

- (3) - 7 ispitanika $(8,5 \%)$

- (4) - 24 ispitanika $(29,3 \%)$

- (5) -51 ispitanik $(62,2 \%)$. 
Nakon toga bilo je potrebno ocijeniti zanimanje zaposlenika za zelene knjižnične usluge. Rezultati su sljedeći:

- (1) - 0 ispitanika (0\%)

- (2) - 3 ispitanika $(3,7 \%)$

- (3) - 26 ispitanika $(31,7 \%)$

- (4) - 36 ispitanika $(43,9 \%)$

- (5) - 17 ispitanika $(20,7 \%)$.

Posljednje pitanje $u$ anketnom upitniku bilo je otvorenog tipa. Ispitanici su mogli navesti što bi još njihova knjižnica mogla napraviti kako bi bila zelenija. Odgovori su se mogli odnositi na sve tri ispitane cjeline - na zgradu, poslovanje i usluge. U nastavku rada prikazani su neki od odgovora.

Pitanje: Što bi još Vaša knjižnica mogla napraviti kako bi postala zelena knjižnica?

- koristiti obnovljive izvore energije u svom radu, organizirati razna događanja s ciljem povećanja ekološke osviještenosti

- uključiti se u postojeće projekte

- svakodnevno osvještavati korisnike

- educirati osnivača knjižnice o potrebi izgradnje zelene knjižnice te općenito javnih objekata s međunarodnim certifikatom zelene gradnje

- poticati mlade članove knjižnice u sadnji stabala u parkovnim zonama grada, osvještavati stanovništvo o potrebi sortiranja kućnog otpada

- organizirati programe kako bismo educirali javnost o nužnosti zaštite okoliša, o klimi, o obnovljivim izvorima energije, o smanjenju potrošnje energije i sl.

- u okolnostima i prostoru u kojem posluje naša knjižnica moguće je: zamjena stolarije, bolje upravljanje hlađenjem-grijanjem, bolje upravljanje utroškom el. energije, povećanje ekološke svijesti zaposlenika

- upoznati se s projektima na nacionalnoj razini koji se tiču zelene knjižnice te se upoznati s izvorima financijske potpore za ostvarivanje projekata

- budući da se knjižnica nalazi u zgradi, secesijskoj vili staroj preko stoljeća, da bi bila zelena knjižnica u pravom smislu riječi, neophodan je novi, namjenski prostor!

- svojim primjerom pobuditi svijest svojih korisnika i posjetitelja kako bi shvatili važnost zaštite okoliša, posebice smanjivanja te zbrinjavanja svih vrsta otpada, racionalnog korištenja energije i vode

- povezivanje i suradnja s ,ekološkim“ ustanovama, organiziranje i promoviranje događanja usmjerenih na zaštitu okoliša 
- pratiti rad europskih knjižnica

- 1) kontinuirano osvještavati ljude o važnosti očuvanja i zaštite okoliša;

2) uključiti djecu i odrasle kako bismo zajedno doprinijeli pravilnom gospodarenju otpada; 3 ) uključiti se u više zelenih projekata

- bespapirno poslovanje, srediti prostor kako bi se umanjio nepotreban gubitak energije (npr. vrata na odjelima), prestati koristiti jednokratnu plastiku, povećati broj aktivnosti (predavanja, radionica) s ekološkim temama koje su izravno povezane sa životima njezinih korisnika

- upravo se nalazimo na privremenoj lokaciji kako bi se provela energetska obnova zgrade u kojoj je knjižnica, a zatim slijede aktivnosti

- Ići prema paperless office konceptu. Ništa drugo jer jednostavno nemamo kapaciteta jer je samo dvoje zaposlenih.

- možda za početak informirati se o tom što znači zelena knjižnica

- ugraditi sustave za grijanje na solarne panele, provesti energetsku obnovu zgrade

- Dodatna edukacija je nužna jer nismo u potpunosti upoznati sa značenjem i konceptom „zelene“ knjižnice. Kako smo smješteni u staroj i oronuloj zgradi, trenutno ne možemo raditi puno više po tom pitanju, osim nekoliko sitnica koje djelatnici već i rade. Prvenstveno je potrebno prijeći u novu zgradu knjižnice i u njoj eventualno razvijati taj koncept.

- Samoinicijativno ništa, ako politika pokrene inicijativu onda se svi slažemo i idemo do realizacije ne štedeći sebe za tu inicijativu.

- imati kontejnere za plastiku

- Obnovljivi izvori energije, ugradnja solarne elektrane na krov zgrade te mini vjetroelektrana u dvorištu knjižnice, no, zbog komplicirane papirologije odustali smo.

- maknuti plastične čaše i tanjuriće

- Odvajamo papir i plastiku, sve materijale koje možemo iskoristiti za kreativne radionice - prikupljamo i koristimo. Korišteni A4 papir ispisan samo na jednoj strani - režemo na 4 komada te lijepimo na zadnju str. knjiga gdje stavljamo štambilj datuma povratka građe. Otpad koji ne možemo iskoristiti odlažemo u reciklažno dvorište. To je ono što mi trenutno radimo.

- Postupke, aktivnosti, programe i sadržaje uskladiti s načelima održivog razvoja i zaštite okoliša. Prije svega potrebna je i podrška Osnivača u ostvarivanju programa ekološke tematike te u budućnosti prostore knjižnice opremiti potrebnim ekološkim certifikatima. Na djelatnicima je da svjesno postupaju i kroz aktivnosti promiču svijest o zaštiti okoliša.

- Bolja edukacija zacijelo bi donijela i veći angažman. 
- Knjižnica radi u malo prostora, podstanari smo u stambenoj zgradi pa su i aktivnosti koje provodimo u okviru nekih od projekata limitirajuće. Stoga je teško postati boljom, zelenijom i angažiranijom knjižnicom. Kad bismo dobili novi prostor, neke projekte provodili bismo kvalitetnije.

- Upravo u Knjižnici Savica začet je projekt Zelena knjižnica za zeleni Zagreb, koji se sada provodi u 21 knjižnici mreže Knjižnica grada Zagreba. Svi njezini djelatnici ulažu velik trud oko zelenih programskih sadržaja i intenzivno surađuju s udrugama, ustanovama i pojedincima koji se bave ekologijom. Nažalost, smještena je u energetski iznimno neučinkovit prostor te promjenu dotrajale stolarije i radijatora koji se ne mogu regulirati zbog visokih investicija koje bi to zahtijevalo, čeka već godinama.

- Nedostaje nam prostora i financija da bismo mogli poduzeti sve korake da postanemo zelena knjižnica.

- Utjecati na svjesnost o važnosti ekologije - veća uključenost škola bila bi poželjna. Organizirana događanja nemaju baš zadovoljavajući odaziv.

- Trenutno se radi na obnovi fasade i uspostavi automatskog sustava grijanja i hlađenja, a u planu je suradnja s ekološkim grupama škola i vrtića te se uključiti u akciju Pokrenimo zelene knjižnice.

- Od početka sljedeće godine uložit ćemo više vremena i pozornosti ekološkim pitanjima te u skladu s tim provoditi programske sadržaje za različite dobne skupine i profile korisnika. S obzirom na to da nemamo vlastitu zgradu, a nije izgledna izgradnja nove „zelene“ knjižnice, stalno nastojimo napraviti bar male pomake u svakodnevnom poslovanju i funkcioniranju knjižnice (npr. nabavili smo veći broj staklenih čaša te sve rjeđe nabavljamo jednokratnu plastiku i sl.).

- Od 2014. godine u knjižnici se kontinuirano održavaju programi koji se mogu smatrati dijelom Zelene knjižnice. Počelo je suradnjom s lokalnom Udrugom ZMAG koja se bavi permakulturom i održivim razvojem, a nastavilo se nizom radionica, predavanja, predstavljanja knjiga, izložbi, prikazivanjem filmova s Okolišnog filmskog festivala. Nekoliko suradnji imamo i s Gradom Velikom Goricom jer se na razini grada provodi nekoliko ekoloških projekata. U budućnosti možemo biti još otvoreniji za nove suradnje, organizirati edukativne čitateljsko-ekološke programe za djecu, daljnje radionice za odrasle... Ako se ostvari naša želja za gradnjom nove zgrade knjižnice, nastojat ćemo da ona bude sagrađena u skladu sa „zelenim“ standardima.

- Gradska knjižnica Makarska trenutno je u fazi selidbe u renovirani, adaptirani prostor. Nakon selidbe u renovirani prostor, u planu je organiziranje zelenih aktivnosti u vidu radionica, seminara i predavanja. 
Također, djelatnici će dobiti upute o štednji električne energije u knjižnici kao što je gašenje računala u vrijeme pauze ili dok nema korisnika u knjižnici.

- Naša je knjižnica eko knjižnica i u njoj je zabranjena upotreba jednokratne plastike. U nastavku već započetog eko projekta nastavljamo s edukacijama predškolske i školske djece različitim oblicima predavanja, radionica, bajkaonica itd.

\subsection{Zaključak istraživanja i rasprava}

Istraživanjem su se potvrdile sve tri postavljene hipoteze:

Hipoteza 1. Zgrade narodnih knjižnica u Hrvatskoj ne razvijaju se u skladu s ekološkom održivosti.

Od 96,3 \% knjižnica koje su odgovorile da knjižnična zgrada nema certifikat za zelenu gradnju njih 75,9 \% odgovorilo je da nije u planu izgradnja nove knjižnične zgrade s takvim certifikatom. Budući da izgradnja nove zgrade zahtijeva velika financijska sredstva koja je knjižnicama teško dobiti, u istraživanju su ispitani elementi uštede energije koje knjižnice mogu uvesti u zgrade, a zahtijevaju puno manja ili nikakva financijska sredstva. Tako na primjer štedne žarulje koristi tek $57,3 \%$ ispitanih knjižnica, a 10,8 \% knjižnica ne koristi niti jednu od ponuđenih mjera štednje (automatsku regulaciju grijanja i rashladnih uređaja, prirodnu ventilaciju, senzore za svjetlo). Prema pojedinim odgovorima, prepreke u izgradnji zelenih knjižničnih zgrada jesu nedostatak financijskih sredstava te čekanje na dokumentaciju.

Hipoteza 2. U knjižnično poslovanje narodnih knjižnica u Hrvatskoj uvode se načela zelenog poslovanja.

U dijelu istraživanja o poslovanju zelenih knjižnica ispitano je koja se načela zelenog ureda knjižnice primjenjuju. I ovdje su ponuđeni elementi zelenog ureda koji su financijski dostupni knjižnicama, a njihovo uvođenje i provođenje ovise o motivaciji rukovoditelja i drugih zaposlenika knjižnice. Među njima je odvajanje papira za reciklažu, što je u svoje poslovanje uvelo 97,6 \% ispitanih knjižnica te štednja papira i tinte obostranim ispisom ili izbjegavanjem ispisa, što čini 92,7 \% knjižnica. Međutim tek u 32,9 \% ispitanih knjižnica ne koristi se jednokratna plastika, a samo njih $28 \%$ navelo je kako isključuju računala za vrijeme stanke. Jedan je od elemenata zelenog poslovanja i suradnja s lokalnom zajednicom na području zaštite okoliša, a istraživanje je pokazalo da to čini 70,7 \% knjižnica. Najviše se surađuje s osnovnim i srednjim školama (80,4\%), a najmanje s fakultetima $(12,5$ $\%)$. 
Hipoteza 3. Sve više narodnih knjižnica u Hrvatskoj zainteresirano je za razvijanje zelenih knjižničnih usluga.

Većina knjižnica koje su sudjelovale u istraživanju (80,5 \%) nije uključena u projekte i programe za zelenu knjižnicu, a njih $60,6 \%$ planira se uključiti. Od ukupnog broja knjižnica njih više od $80 \%$ organizira događanja posvećena temama iz ekologije, ponajviše radionice, predavanja i izložbe. Nešto više od 73 \% knjižnica ta događanja promovira na svojim mrežnim stranicama i društvenim mrežama. $\mathrm{O}$ zainteresiranosti knjižnica za zelene aktivnosti i programe svjedoče odgovori na posljednje pitanje, gdje su ispitanici mogli navesti što bi njihove knjižnice još mogle napraviti kako bi postale zelene knjižnice. Velik broj ispitanika naveo je da je potrebno uključiti se u postojeće projekte, organizirati događanja ekološke tematike te raditi na njihovoj promociji kako bi i odaziv na događanja bio veći.

Osim što su istraživanjem potvrđene hipoteze, ono je također pokazalo da bi prepreka širenju pokreta zelenih knjižnica među narodnim knjižnicama u Hrvatskoj mogla biti nedovoljna educiranost zaposlenika o konceptu zelene knjižnice, nedostatak knjižničarskog osoblja te nezainteresiranost osoblja za koncept zelene knjižnice. Svoju upoznatost $\mathrm{s}$ konceptom zelene knjižnice najviše ispitanika ocijenilo je srednjom ocjenom (3), iz čega se može zaključiti da treba više raditi na edukaciji knjižničara o zelenim knjižnicama i ulozi narodnih knjižnica u obrazovanju za okoliš. Nekoliko ispitanika istaknulo je kako bez zelene knjižnične zgrade knjižnica ne može puno napraviti po pitanju zaštite okoliša ne uzimajući pritom u obzir knjižnično poslovanje te usluge i aktivnosti kojima zelene knjižnice doprinose zaštiti okoliša. Sljedeća prepreka odnosi se na nedostatak vremena za provođenje zelenih aktivnosti zbog nedostatka knjižničarskog osoblja. Nedovoljna ekološka osviještenost zaposlenika također može biti prepreka širenju koncepta zelene knjižnice, a kao posljedica proizlazi neprovođenje zelenih aktivnosti i programa.

\section{Zaključak}

Uništavanje okoliša iskorištavanjem prirodnih resursa i stvaranjem velike količine otpada problem je koji društvo treba rješavati ako želi opstati, a trebaju ga rješavati institucije i pojedinci. Knjižnice pritom imaju zadaću širenja informacija i razvijanja ekološke svijesti. Koliko će se knjižnice posvetiti promicanju ekološke osviještenosti i ciljeva održivog razvoja u zajednici, ovisi o educiranosti i osviještenosti samih zaposlenika i rukovoditelja knjižnice. Oni su ti koji organiziraju te provode aktivnosti i programe posvećene temama iz područja ekologije. Isto tako, knjižnice mogu uvesti niz mjera kojima bi njihovo poslovanje bilo ekološki prihvatljivije. Radi se o malim koracima koji zahtijevaju i manja financijska ulaganja, a rezultiraju uštedom energije i resursa, pa samim time i novčanih sredstava knjižnice. 
Istraživanje provedeno u 82 narodne knjižnice u Hrvatskoj pokazalo je da većina knjižnica u zgradama ne provodi financijski dostupne mjere štednje energije, ali da su neka od načela zelenog poslovanja ipak zastupljena u poslovanju (odvajanje papira za reciklažu te štednja papira i tinte u većini knjižnica). Utvrđeno je da su narodne knjižnice u Hrvatskoj zainteresirane za razvijanje zelenih knjižničnih usluga te da većina knjižnica u svoj program uvrštava i događanja ekološke tematike. Međutim, isto tako iz provedene ankete proizlazi da je potrebno educirati knjižničare o konceptu zelene knjižnice, motivirati ih te kod njih razvijati ekološku svijest. Osim nedovoljne educiranosti ili zainteresiranosti zaposlenika za koncept zelene knjižnice, pokazalo se da prepreka razvoju narodnih knjižnica u Hrvatskoj u zelenom smjeru mogu biti nedovoljan broj knjižničnog osoblja, neodgovarajući prostor te nedostatak financijskih sredstava. Problemi su to s kojima se danas suočavaju brojne narodne knjižnice.

Provedeno istraživanje možda je neke knjižnice potaknulo da razmisle o okretanju u smjeru zelene knjižnice uvođenjem pojedinih mjera štednje energije u zgradi i načela zelenog poslovanja te razvijanjem zelenih knjižničnih usluga kroz uključivanje u nekih od postojećih projekata za zelenu knjižnicu, razvijanjem vlastitih zelenih programa ili povećanjem broja događanja ekološke tematike te da općenito nizom malih promjena, u skladu s financijskim, prostornim i vremenskim mogućnostima, doprinesu očuvanju zajednice kojoj služe.

\section{LITERATURA}

Bačić, E. Zagovaranje za knjižnice i partnerstvo za održivi razvoj. // Vjesnik bibliotekara Hrvatske 61, 2(2018), 367-380. Dostupno i na: https://www.hkdrustvo.hr/ vjesnik-bibliotekara-hrvatske/index.php/vbh/article/view/707/608 [citirano: 201907-16].

Čadovska, I.; A.-M. Tkalčić. Zelena pismenost kao dio strategije razvoja informacijske službe. // Vjesnik bibliotekara Hrvatske 60, 1(2017), 65-77.

Ekonomski fakultet u Osijeku. Okrugli stol. [citirano: 2019-07-26]. Dostupno na: http:// www.efos.unios.hr/knjiznica/okrugli-stol/.

Hrvatsko knjižničarsko društvo. 39. skupština Hrvatskoga knjižničarskog društva. [citirano: 2019-07-26]. Dostupno na: http://hkdrustvo.hr/hr/skupovi/skup/241/.

Hrvatsko knjižničarsko društvo. 41. skupština Hrvatskoga knjižničarskog društva. [citirano: 2019-07-26]. Dostupno na: http://hkdrustvo.hr/hr/skupovi/skup/302/.

IFLA. About the Environment, Sustainability and Libraries Special Interest Group. [citirano: 2019-08-09]. Dostupno na: https://www.ifla.org/about-environmental-sustainability-and-libraries. 
IFLA. IFLA Green Library Award. [citirano: 2019-08-09]. Dostupno na: https://www. ifla.org/node/10159.

Izvještaj Radne grupe za zelene knjižnice za 2015. godinu. [citirano: 2019-07-26]. Dostupno na: http://hkdrustvo.hr/hr/strucna_tijela/50/publikacije.

Izvještaj Radne grupe za zelene knjižnice za 2016. godinu. [citirano: 2019-07-26]. Dostupno na: http://hkdrustvo.hr/hr/strucna_tijela/50/publikacije.

Izvještaj Radne grupe za zelene knjižnice za period 01.09.2017. do 31.08.2018. god. [citirano: 2019-07-26]. Dostupno na: http://hkdrustvo.hr/hr/strucna_tijela/50/publikacije.

Kraljević, I. Djelovanje radne grupe za zelene knjižnice: 2014.-2018. // Vjesnik bibliotekara Hrvatske 62, 1(2019), 327-340. Dostupno i na: http://www.hkdrustvo.hr/ vjesnik-bibliotekara-hrvatske/index.php/vbh/article/view/720/640 [citirano: 201907-26].

Kraljević, I. Zelena knjižnica: projekt Društva bibliotekara Istre. // Vjesnik bibliotekara Hrvatske 56, 3(2013), 199-204. Dostupno i na: https://www.hkdrustvo.hr/vjesnik-bibliotekara-hrvatske/index.php/vbh/article/view/170 [citirano: 2019-07-26].

Nacionalna i sveučilišna knjižnica u Zagrebu. „Zelene knjižnice“: održan okrugli stol o knjižnicama kao predvodnicama ekološki održivoga razvoja. [citirano: 2019-07-29]. Dostupno na: http://www.nsk.hr/zelene-knjiznice-odrzan-okrugli-stol-o-knjiznicama-kao-predvodnicama-ekoloski-odrzivoga-razvoja/.

Poticanje energetske efikasnosti u Hrvatskoj. Društveno odgovorno poslovanje. [citirano 2019-07-16]. Dostupno na: http://www.enu.fzoeu.hr/hio/zeleni-ured/drustveno-odgovorno-poslovanje.

Projekt Zelena knjižnica za zelenu Hrvatsku. // HKD Novosti 73(2017). [citirano: 201907-29]. Dostupno na: http://www.hkdrustvo.hr/hkdnovosti/clanak/1331.

Radna grupa za zelene knjižnice - Plan i program. [citirano: 2019-07-29]. Dostupno na: https://www.hkdrustvo.hr/hr/strucna_tijela/50/plan_i_program/.

Radna grupa za zelene knjižnice - Uvod. [citirano: 2019-07-26]. Dostupno na: https:// www.hkdrustvo.hr/hr/strucna_tijela/50.

Sahavirta, H. Set the wheels in motion - clarifying "green library" as a goal for action. // Libraries: dialogue for change / IFLA World Library and Information Congress (WLIC) 2019, Atena. [citirano: 2019-08-27]. Dostupno na: http://library.ifla.org/2568/1/166-sahavirta-en.pdf.

Sustainable library. // Online Dictionary of Library and Information Science. [citirano: 2019-07-16]. Dostupno na: https://www.abc-clio.com/ODLIS/odlis_s.aspx\#sustainablelib.

Vodič kroz Zeleni ured: Priručnik. [citirano 2019-07-16]. Dostupno na: http://www.enu. fzoeu.hr/assets/files/shared/list/zuPrirucnik.pdf. 


\section{Prilog 1: Anketni upitnik}

Poštovani,

ovaj upitnik provodi se u svrhu izrade diplomskog rada na studiju bibliotekarstva na Filozofskom fakultetu Sveučilišta u Zagrebu. Cilj je rada istražiti razvoj narodnih knjižnica u Hrvatskoj prema zelenim knjižnicama. Namijenjen je ispunjavanju od strane ravnatelja samostalnih knjižnica, voditelja knjižnica u sastavu odnosno područnih knjižnica te koordinatora ogranaka narodnih knjižnica u Republici Hrvatskoj. Pitanja koja slijede odnose se na narodnu knjižnicu kojom upravljate, a tematski su podijeljena na tri kategorije: zgrada knjižnice, poslovanje zelene knjižnice te knjižnične usluge.

Ispunjavanje upitnika traje oko 5 minuta.

U slučaju bilo kakvih nejasnoća možete se obratiti na e-mail azecevic@ffzg.hr.

Unaprijed hvala na izdvojenom vremenu!

Studentica: $x x x x x x$

Mentor: $\mathrm{xxxxxx}$

Naziv narodne knjižnice:

\section{Adresa:}

\section{Tip knjižnice:}

o Samostalna

○ U sastavu

- Područna

o Ogranak

\section{Vaša funkcija:}

○ ravnatelj

$\circ$ voditelj

$\circ$ koordinator

○ druga funkcija:

\section{Zgrada knjižnice}

1. Zgrada knjižnice posjeduje certifikat za zelenu gradnju.
○ DA
$\circ \mathrm{NE}$ 
2. Ako ste na prethodno pitanje odgovorili negativno, planira li se izgradnja nove knjižnične zgrade s certifikatom za zelenu gradnju?
$\circ$ DA
$\circ \mathrm{NE}$

3. Koje mjere štednje energije već primjenjujete u zgradi knjižnice? (moguće je označiti više odgovora)

$\square$ automatska regulacija rashladnih uređaja (isključivanje kada u knjižnici nema korisnika niti zaposlenih, tj. kada je knjižnica prazna)

$\square$ automatska regulacija grijanja (isključivanje kada u knjižnici nema korisnika niti zaposlenih, tj. kada je knjižnica prazna)

$\square$ senzori za svjetlo

$\square$ štedne žarulje

$\square$ prirodna ventilacija

$\square$ korištenje obnovljivih izvora energije

$\square$ ostalo:

\section{Poslovanje zelene knjižnice}

4. Ima li knjižnica na svojoj mrežnoj stranici oznaku zelene knjižnice?

$\circ$ DA

$\circ \mathrm{NE}$

5. Koja od sljedećih načela „zelenog ureda“ knjižnica već primjenjuje? (moguće je označiti više odgovora)

$\square$ odvajanje papira za reciklažu

$\square$ isključivanje računala za vrijeme pauze

$\square$ štednja papira i tinte (obostrani ispis, izbjegavanje ispisa i sl.)

$\square$ nekorištenje jednokratne plastike (plastične čaše i dr.)

$\square$ ostalo:

6. Surađuje li knjižnica s ustanovama, udrugama i pojedincima iz područja ekologije?

$\circ$ DA

$\circ \mathrm{NE}$

7. Ako je Vaš odgovor na prethodno pitanje bio negativan, molimo Vas preskočite ovo pitanje. Ako je Vaš odgovor na prethodno pitanje bio pozitivan, 
molimo Vas da navedete s kim knjižnica surađuje u provođenju zelenih knjižničnih programa. (moguće je označiti više odgovora)
$\square$ s osnovnim i srednjim školama
$\square$ s fakultetima
$\square$ s udrugama
$\square$ s pojedinim stručnjacima
$\square$ s drugim knjižnicama
$\square \mathrm{s}$ gradom
$\square$ s općinom
$\square$ ostalo:

8. Procijenite koliko dobro ste upoznati s konceptom zelene knjižnice.

Nisam upoznat/a 12345 Odlično

\section{Knjižnične usluge}

9. Knjižnica posjeduje tiskanu i/ili elektroničku građu iz područja zaštite i očuvanja okoliša.
$\circ$ DA
$\circ \mathrm{NE}$

10. Knjižnica je uključena u neki od postojećih projekata i programa za zelenu knjižnicu (Pokrenimo zelene knjižnice, Zelene knjižnice za zeleni Zagreb, ZeeK i dr.).
$\circ$ DA
$\circ \mathrm{NE}$

11. Ako je Vaš odgovor na prethodno pitanje bio pozitivan, molimo Vas da navedete naziv projekta ili programa.

12. Ako ste pozitivno odgovorili na 10. pitanje, molimo preskočite ovo pitanje. Ako je Vaš odgovor na 10. pitanje bio negativan, planira li se knjižnica uključiti u projekte za zelenu knjižnicu?
○ DA
$\circ \mathrm{NE}$

13. Organizira li knjižnica događanja ekološke tematike?
$\circ$ DA
$\circ \mathrm{NE}$ 
14. Ako je Vaš odgovor na prethodno pitanje bio pozitivan, molimo Vas da navedete koja događanja ekološke tematike su već održana ili se provode. (moguće je označiti više odgovora)

$\square$ predavanja

$\square$ seminari

$\square$ tribine za javnost

$\square$ izložbe

$\square$ radionice

$\square$ projekcije filmova

$\square$ predstave

$\square$ ostalo:

15. Promovira li knjižnica svoje zelene aktivnosti?
$\circ$ DA
$\circ \mathrm{NE}$

16. Ako je Vaš odgovor na prethodno pitanje bio pozitivan, molimo Vas da navedete gdje knjižnica promovira svoje zelene aktivnosti. (moguće je označiti više odgovora)
$\square$ na svojoj mrežnoj stranici
$\square$ na društvenim mrežama
$\square \mathrm{u}$ newsletteru
$\square$ na plakatima
$\square$ ostalo:

17. Prema Vašem mišljenju, koliko je važno da se narodne knjižnice svojim uslugama (zbirkama i organiziranjem događanja) uključe u izobrazbu o zaštiti okoliša?

Potpuno nevažno 12345 Vrlo važno

18. Ocijenite zanimanje zaposlenika za zelene knjižnične usluge. Potpuno nezainteresirani 12345 Vrlo zainteresirani

19. Što bi još Vaša knjižnica mogla napraviti kako bi postala zelena knjižnica? 